\title{
Pengaruh Penerapan Prinsip GCG pada Persepsi Kualitas Informasi Keuangan PERUMDA Air Minum Tirta Sewaka Darma
}

\author{
Gede Rudi Harta Pratama Giri ${ }^{1}$ \\ Fakultas Ekonomi dan Bisnis \\ Universitas Udayana, Indonesia \\ Email: ruhapagi@gmail.com
}

\author{
Ni Luh Supadmi² \\ Fakultas Ekonomi dan Bisnis \\ Universitas Udayana, Indonesia
}

\begin{abstract}
ABSTRAK
Tujuan dari penelitian ini adalah untuk mengkaji secara empiris pengaruh prinsip transparansi, akuntabilitas, pertanggungjawaban, kemandirian dan kewajaran/kesetaraan. Penelitian ini dilakukan di PERUMDA Air Minum Tirta Sewaka Darma dengan pendekatan kuantitatif yang berbentuk asosiatif. Penelitian ini menggunakan data primer data sekunder. Populasi sebanyak 340 karyawan dan sampel dipilih menggunakan teknik purposive sampling sebanyak 56 karyawan. Teknik analisis data adalah regresi linear berganda. Berdasarkan hasil penelitian menunjukkan bahwa transparansi, akuntabilitas, pertanggungjawban, kemandirian dan kewajaran/kesetaraan berpengaruh positif dan signifikan terhadap kualitas informasi keuangan.
\end{abstract}

Kata Kunci: Transparansi; Akuntabilitas;Pertanggungjawaban; Kemandirian; Kewajaran/Kesetaraan.

\section{The Effect of Implementation GCG Principles on Financial Information Quality Perception PERUMDA Air Minum Tirta Sewaka Darma}

\section{ABSTRACT}

The purpose of this study is to empirically assess the principle of transparency, accountability, accountability, independence and fairness/equality. This research was conducted at PERUMDA Air Minum Tirta Sewaka Darma with a quantitative approach that is in the form of associative. This research uses primary data of secondary data. A population of 340 employees and samples were selected using the purposive sampling technique of 56 employees. Data analysis techniques are double linear regression. Based on the results shows that transparency, accountability, responsibility, independence and fairness/equality influence positive and significant to the quality of financial information.

Keywords: Transparency; Accountability; Responsibility, Independency; Fairness.

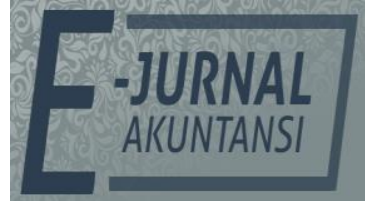

E-JA

e-Jurnal Akuntansi e-ISSN 2302-8556

Vol. 30 No. 2

Denpasar, Februari 2020

Hal. 293-306

Artikel Masuk:

2 Desember 2019

Tanggal Diterima:

9 Januari 2020 


\section{PENDAHULUAN}

Laporan keuangan adalah ringkasan proses pencatatan transaksi keuangan yang terjadi selama satu tahun buku yang bersangkutan dan suatu bentuk pertanggungjawaban pemerintah kepada rakyat atas pengelolaan dana publik baik dari pajak, retribusi atau transaksi lainnya. Badan statistik banyak menggunakan laporan tahunan perusahaan untuk berbagai perkembangan yang memungkinkan menentukan arah dan tingkat pengembangan produksi perusahaan (Osadchy et al., 2018). Kualitas informasi keuangan sangat penting untuk diperhatikan karena memberikan manfaat dalam pengambilan keputusan ekonomi serta dapat mengetahui kondisi keuangan perusahaan. Kualitas informasi keuangan perusahaan dipengaruhi oleh peranan tata kelola perusahaan. Barrett (1997) menyatakan bahwa sebuah perusahaan dapat mengembangkan tata kelola perusahaan yang baik untuk memaksimalkan kualitas perusahaan. Kualitas tata kelola perusahaan yaitu kondisi yang diperlukan untuk memastikan dan mempertahankan kepercayaan para pemangku kepentingan (Fathi, 2013). Organization for Economic Cooperation and Development (OECD) mendefinisikan corporate governance digunakan untuk mengendalikan serta mengarahkan kegiatan dalam perusahaan (Chaarani, 2014). Peningkatan kualitas keuangan perusahaan perlu diikuti oleh pengelolaan yang diterapkan secara konsisten. Strategi harus dimiliki oleh perusahaan untuk dapat bersaing melalui penerapan tata kelola perusahaan yang baik.

Good Corporate Governance yaitu sebuah konsep yang menekankan pentingnya hak pemegang saham untuk memperoleh informasi yang akurat, benar dan tepat waktu. Selain itu juga menunjukkan kewajiban perusahaan untuk mengungkapkan semua informasi keuangan kinerja perusahaan secara akurat, tepat waktu, dan transparan, (Sejati, 2018). Good Corporate Governance (GCG) berperan dalam mengatur serta mengendalikan perusahaan sehingga mampu meningkatkan kepercayaan stakeholder dalam memperoleh informasi keuangan perusahaan yang disampaikan secara akurat tepat waktu dan transparan (YPPMI, 2002). Good Corporate Governance (GCG) didefinisikan sebagai sistem dimana perusahaan dapat dikontrol dan diarahkan (Kamazima et al., 2017). Good Corporate Governance (GCG) lebih ditujukan untuk sistem pengendalian dan pengaturan perusahaan dengan tindakan yang dilakukan eksekutif perusahaan agar tidak merugikan para stakeholder karena GCG menyangkut moralitas etika kerja dan prinsip-prinsip kerja yang baik (Sari, 2015). Hart (1995) mengatakan corporate governance muncul dalam organisasi disebabkan karena adanya masalah agensi atau konflik kepentingan yang melibatkan anggota organisasi.

Dilansir dari pemberitaan online Perpamsi.or.id pada tanggal 23 Januari 2017 PERUMDA Air Minum Tirta Sewakadarma melakukan penandatanganan pengesahan Good Corporate Governance di aula PERUMDA Air Minum Tirta Sewakadarma. Penandatangan ini menandai telah disusunnya pedoman GCG yang difasilitasi oleh Badan Pemeriksa Keuangan Pembangunan (BPKP) Provinsi Bali. Pada tahun 2006 Komite Nasional Kebijakan Governance (KNKG) menerbitkan pedoman pelaksanaan good corporate governance sebagai dorongan agar perusahaan mampu menciptakan sistem tata kelola yang sehat. Komisi Nasional Kebiijakan Governance, (2006) menyebutkan lima prinsip GCG yaitu 
transparansi (transparancy), akuntabilitas (accountability), pertanggungjawaban (responsibility), kemandirian (independency) dan kesetaraan dan kewajaran (fairness). Prinip-prinip Good Corporate Governance diterapkan agar menghasilkan laporan keuangan yang dapat diungkapkan secara transparan dan akurat sehingga dapat membantu investor serta pihak-pihak lain yang berkepentingan dalam suatu perusahaan untuk mengambil keputusan sehingga dapat meningkatkan kinerja keuangan perusahaan (Rahmatika dan Agusti, 2015). PERUMDA Air Minum berperan dalam melaksanakan pembangunan daerah dan nasional melalui penyediaan air bersih dan sehat serta memberikan pelayanan secara jujur dan transparan. Penilaian kinerja keuangan PERUMDA Air Minum Tirta Sewaka Darma mengalami penurunan laba dari tahun 2015 sampai 2017. Hal ini menunjukkan biaya yang dikeluarkan untuk mencapai penghasilan kurang efisien sedangkan rasio operasinya mengalami peningkatan. Badan Peningkatan Penyelenggaraan Sistem Penyediaan Air Minum (BPPSPAM) kinerja PERUMDA Air Minum Tirta Sewaka Darma yang terdiri dari kategori bidang keuangan dan bidang pelayanan menunjukkan data sebagai berikut.

Tabel 1. Laporan Kinerja Keuangan PERUMDA Air Minum Tirta Sewaka Darma tahun 2015-2017

\begin{tabular}{|c|c|c|c|c|}
\hline No. & Keterangan & $\begin{array}{l}2015 \\
(\%)\end{array}$ & $\begin{array}{l}2016 \\
(\%)\end{array}$ & $\begin{array}{l}2017 \\
(\%)\end{array}$ \\
\hline \multirow[t]{8}{*}{ A. } & \multicolumn{4}{|l|}{ Bidang Keuangan } \\
\hline & \multicolumn{4}{|l|}{ 1. Rentabilitas } \\
\hline & a. ROE & 16,28 & 7,26 & 5,66 \\
\hline & b. Ratio Operasi & 0,86 & 0,90 & 0,92 \\
\hline & \multicolumn{4}{|l|}{ 2. Likuiditas } \\
\hline & a. Ratio Kas & 86,39 & 121,44 & 175,28 \\
\hline & b. Efektivitas Penagihan & 99,13 & 97,56 & 97,70 \\
\hline & 3. Solvabilitas & 144,76 & 460,36 & 574,51 \\
\hline \multicolumn{2}{|c|}{ Total Nilai Kinerja Bidang Keuangan } & 0,97 & 1,03 & 0,98 \\
\hline \multirow[b]{7}{*}{ Total } & \multicolumn{4}{|l|}{ Bidang Pelayanan } \\
\hline & 1. Cakupan Pelayanan & 45,55 & 49,17 & 48,59 \\
\hline & 2. Pertumbuhan Pelanggan & 4,29 & 2,49 & 1,36 \\
\hline & 3. Tingkat Penyelesaian Pengaduan & 99,96 & 99,96 & 99,96 \\
\hline & 4. Kualitas Air Pelanggan & 100,00 & 100,00 & 100,00 \\
\hline & 5. Konsumsi Air Domestik & 24,65 & 24,00 & 22,36 \\
\hline & Nilai Kinerja Bidang Pelayanan & 0,90 & 0,85 & 0,85 \\
\hline
\end{tabular}

Sumber: Data Penelitian, 2019

Berdasarkan Tabel 1. kinerja PERUMDA Air Minum Tirta Sewaka Darma di Bidang Keuangan dari Tahun 2015 sampai 2017 mengalami fluktuasi dan di Bidang Pelayanan mengalami penurunan di tahun 2015 sebesar 0,90 menjadi di tahun 2016 dan 2017 sebesar 0,85. Kinerja keuangan dapat dikatakan sehat jika perusahaan dapat menjalankan kegiatan bisnis dan manajemen yang baik sehingga diharapkan akan menghasilkan konsumen yang puas dengan pelayanan PERUMDA Air Minum.

Penelitian mengenai GCG telah banyak diteliti namun masih sedikit yang menggunakan PERUMDA Air Minum sebagai obyek. Peneliti tertarik menggunakan PERUMDA Air Minum sebagai obyek karena ingin mengetahui secara empiris pengaruh GCG pada persepsi kualitas informasi keuangan setelah 
diterapkan pada tanggal 20 Januari 2017. Peneliti juga tertarik meneliti PERUMDA Air Minum karena terdapat fenomena yang ditemukan dalam laporan kinerja keuangan PERUMDA Air Minum tahun 2015-2017. Laporan kinerja keuangan PERUMDA Air Minum mengalami fluktuasi pada bidang keuangan tahun 2015-2017. Bidang pelayanan mengalami penurunan dari tahun 2015 sampai 2016 dan tetap pada tahun 2017. Informasi yang tertuang dalam laporan kinerja keuangan PERUMDA Air Minum akan menimbulkan sebuah persepsi. Persepsi dari pengguna atau pembuat informasi mungkin saja berbeda, sehingga persepsi kualitas informasi keuangan pada PERUMDA Air Minum penting untuk diteliti. Hindistari (2016),. menyatakan bahwa prinsip-prinsip GCG berpengaruh positif pada kinerja Bank Perkreditan Rakyat (BPR) di Kabupaten Gianyar. Noviolanita (2015) menyatakan penerapan prinsip-prinsip GCG berpengaruh positif pada kualitas laporan keuangan PT PLN (Persero) distribusi Jawa Barat dan Banten Mahaendrayasa (2017) mengatakan prinsip transparency dan responsibility tidak berpengaruh terhadap kinerja keuangan LPD di Kota Denpasar.

Berdasarkan latar belakang masalah maka dirumuskan masalah penelitian yaitu apakah prinsip transparansi, akuntabilitas, pertanggungjawaban, kemandirian, dan kewajaran/kesetaraan berpengaruh pada persepsi kualitas informasi keuangan PERUMDA Air Minum Tirta Sewaka Darma. Tujuan penelitian ini untuk mengkaji secara empiris pengaruh prinsip transparansi, akuntabilitas, pertanggungjawaban, kemandirian, dan kewajaran/kesetaraan pada persepsi kualitas informasi keuangan PERUMDA Air Minum Tirta Sewaka Darma. Manfaat teoritis dalam penelitian ini yaitu mendukung teori keagenan dan teori Stewardship. Manfaat praktis bagi pengelola perusahaan diharapkan hasil penelitian ini dapat memberikan gambaran yang bermanfaat dalam meningkatkan kualitas informasi keuangan perusahaan. Bagi para peneliti penelitian ini diharapkan dapat menjadi referensi dan mendorong penelitian yang lebih lanjut melalui penambahan variabel yang belum termasuk dalam penelitian ini.

Teori keagenan (agency theory) merupakan basis teori yang mendasari praktik bisnis perusahaan yang dipakai selama ini. Prinsip utamanya hubungan kerja antara pihak yang memberi wewenang (prinsipal) yaitu investor dengan pihak yang menerima wewenang (agensi) yaitu manajer dalam bentuk kontrak kerja sama yang disebut nexus of contract (Jensen dan Meckling, 1976). Tata kelola perusahaan pada dasarnya merupakan mekanisme untuk mengatasi masalah keagenan dan mengendalikan risiko dalam perusahaan (Emilia Peni et al., 2002). Teori agen muncul berdasarkan adanya fenomena pemisahaan antara pemilik perusahaan dengan para manajer yang mengelola perusahaan (Rahmatika dan Agusti, 2015). Untuk meminimalkan berbagai mekanisme GCG yang ditujukan untuk menyelaraskan kepentingan agen dengan kepentingan para pelaku (M'Ithiria dan Musyoki, 2014). Menurut Eisenhardt (1989) agency theory menggunakan tiga asumsi sifat manusia antara lain manusia pada umumnya mementingkan diri sendiri (self interest) manusia memiliki daya pikir terbatas mengenai persepsi masa mendatang (bounded rationality), dan manusia selalu menghindari risiko (risk averse). 
Pada tahun 1991 Donaldson dan Davis mencetuskan teori stewardship. Teori ini menggambarkan situasi para manajer tidak termotivasi oleh tujuantujuan individu tetap lebih merujuk kepada sasaran hasil utama untuk kepentingan organisasi bahwa pihak manajemen sebagai steward memiliki dasar psikologi dan sosiologi untuk bertindak sesuai dengan keinginan principal selain itu, steward akan berusaha untuk mencapai sasaran organisasinya sehingga steward tidak akan meninggalkan organisasi (Riyadi \& Yulianto, 2014).

Good Corporate Governance adalah suatu sistem yang mengendalikan dan mengatur pengelolaan perusahaan yang baik (Putri dan Wirajaya, 2017). Good Corporate Governance merupakan suatu proses dan struktur yang digunakan oleh organisasi untuk meningkatkan keberhasilan usaha dan akuntabilitas perusahaan guna mewujudkan nilai pemegang saham dalam jangka panjang dengan tetap memperhatikan kepentingan berbagai pihak yang berlandaskan peraturan perundangan dan nilai-nilai etika (Arifin, 2018). Good Corporate Governance (GCG) menjadi isu penting di Indonesia karena dapat memberikan nilai lebih bagi perusahaan yang menerapkan GCG sehingga dapat bersaing secara global. Good corporate governance merupakan suatu mekanisme yang dapat memperbaiki ketidakefektivan manajemen perusahaan (Vintila dan Gherghina, 2012). Komite Nasional Kebijakan Governance (2006) mengungkapkan setiap perusahaan harus memastikan bahwa prinsip-prinsip GCG diterapkan pada setiap aspek bisnis dan di semua jajaran perusahaan. Pelaksanaan kegiatan usaha organisasi bisnis harus menganut kelima prinsip-prinsip yang telah ditetapkan oleh KNKG (Pradnyaswari dan Putri, 2016). Menurut Komite Nasional Kebijakan Governance (2006) adapun lima prinsip yang menjadi pedoman pelaksanaan GCG antara lain, transparansi, akuntabilitas, pertanggungjawaban, kemandirian, dan kewajaran/kesetaraan.

Kualitas informas keuangan bersifat multidimensi yang berarti bahwa organisasi harus menggunakan beberapa langkah untuk mengevaluasi kualitas informasi. Penyusunan laporan keuangan penting untuk keberhasilan pelaksanaan kegiatan perusahaan serta untuk menjaga hubungan perusahaan dengan pemerintahaan (Gapsalamov et al., 2017). Gordon (2002: 32) menyatakan informasi merupakan data yang telah diolah ke dalam suatu bentuk yang berguna bagi penerimanya dan nyata atau nilai yang dapat dipahami didalam keputusan sekarang maupun masa depan. Menurut Haque dan Kirkpatrick (2008) sangat penting untuk perusahaan membuat informasi keuangan dan non keuangan yang mudah diakses oleh orang luar agar orang dapat membuat keputusan. Terdapat empat karakteristik pokok kualitas informasi keuangan (Ikatan Akuntan Indonesia, 2007), keempat karakteristik merupakan prasyarat normatif yang diperlukan agar informasi keuangan dapat memenuhi kualitas yang dikehendaki, adapun empat karakteristik tersebut ialah: Relevan, Andal, Dapat dibandingkan, dan dapat dipahami. Teori keagenan menggambarkan bahwa agen lebih banyak tahu tentang informasi perusahaan, sehingga untuk menghindari terjadinya asimetri informasi diperlukan keterbukaan informasi atau transparansi. Transparansi memberikan informasi keuangan yang terbuka dan jujur kepada principal berdasarkan pertimbangan bahwa principal memiliki hak untuk mengetahui secara terbuka dan menyeluruh atas pertanggung jawaban agen dalam pengelolaan sumber daya yang dipercayakan kepadanya 
(Mursyidi, 2009). Transparansi penting dalam sebuah perusahaan karena berhubungan dengan informasi keuangan maupun non keuangan yang akan disajikan oleh agen kepada principal. Penelitian yang dilakukan oleh Taufan (2016), menyatakan bahwa variabel transparansi berpengaruh signifikan terhadap kualitas laporan keuangan daerah Bandung. Berdasarkan hal ini maka hipotesis penelitian yaitu.

$\mathrm{H}_{1}$ : Transparansi berpengaruh positif terhadap persepsi kualitas informasi keuangan PERUMDA Air Minum Tirta Sewaka Darma.

Salah satu standar dalam penggunaan administrasi yang baik adalah akuntabilitas (Dewi et al., 2019). Prinsip akuntabilitas sejalan dengan teori agen dimana dua pihakk yang ada dalam konsep akuntabilitas dideskripsikan sebagai principal dan agent. Principal diartikan sebagai pihak yang harus diberikan pertanggungjawaban dan agent dimaksudkan sebagai pihak yang melakukan pertanggungjawaban. Penelitian (Devi, 2018) menyatakan bahwa prinsip akuntabilitas berpengaruh positif pada kualitas informasi keuangan. Berdasarkan hal ini, maka hipotesis penelitian, yaitu.

$\mathrm{H}_{2}$ : Akuntabilitas berpengaruh positif terhadap persepsi kualitas informasi keuangan PERUMDA Air Minum Tirta Sewaka Darma.

Pertanggungjawaban perusahaan merupakan kesesuaian tata kelola perusahaan pada peraturan perundangan serta prinsip-prinsip perusahaan yang sehat. Teori stewardship menggambarkan manajer tidak termotivasi oleh tujuantujuan individu tetapi lebih merujuk kepada sasaran hasil utama demi kepentingan organisasi (Riyadi dan Yulianto, 2014). Penelitian (Devi, 2018) bahwa prinsip pertanggungjawaban berpengaruh positif pada kualitas informasi keuangan. Berdasarkan hal ini, maka hipotesis penelitian yaitu.

$\mathrm{H}_{3}$ : Pertanggungjawaban berpengaruh positif terhadap persepsi kualitas informasi keuangan PERUMDA Air Minum Tirta Sewaka Darma.

Independensi merupakan bentuk pengambilani keputusani secara objektif, sehingga pengelolaan perusaahaan harus dilakukan secara independen yaitu tidak saling mempengaruhi maupun saling mendominasi. Sesuai dengan teori stewardship dimana kepentingan bersama dijadikan dasar dari tindakan manajer. Sehingga manajer tidak mudah terpengaruh dengan kepentingan-kepentingan lainnya dan berusaha sebaik mungkin dalam menyampaikan informasi keuangan demi tujuan perusahaannya. Penelitian (Devi, 2018) menyatakan bahwa prinsip kemandirian berpengaruh positif pada kualitas informasi keuangan. Berdasarkan hal ini, maka hipotesis penelitian yaitu.

$\mathrm{H}_{4}$ : Kemandirian berpengaruh positif terhadap persepsi kualitas informasi keuangan PERUMDA Air Minum Tirta Sewaka Darma.

Aktivitas operasional perusahaan memerlukan perhatian yang berhubungan tentang kepentingan para stakeholder berdasarkan prinsip kesetaraan dan kewajaran. Hubungan antara agen dan principal harus saling memberi umpan balik sehingga agen akan memberikan informasi keuangan sesuai dengan apa yang diharapkan principal untuk itu kesetaraan dalam perusahaan penting. Sehingga dapat dikatakan kewajaran dan kesetaraan berpengaruh dalam pencapaian kualitas informasi keuangan. Penelitian Devi, (2018) menyatakan bahwa prinsip kewajaran dan kesetaraan berpengaruh positif pada kualitas informasi keuangan. Berdasarkan hal ini, maka hipotesis penelitian, yaitu. 
$\mathrm{H}_{5}$ : Kewajaran dan Kesetaraan berpengaruh positif terhadap persepsi kualitas informasi keuangan PERUMDA Air Minum Tirta Sewaka Darma.

\section{METODE PENELITIAN}

Penelitian ini menggunakan pendekatan kuantitatif yang berbentuk asosiatif. Jenis data dalam penelitian ini data kuantitatif dan data kuantitatif. Metode penentuan sampel yang digunakan adalah purposive sampling. Variabel bebas dalam penelitian ini, yaitu transaparansi $\left(X_{1}\right)$, akuntabilitas $\left(X_{2}\right)$, pertanggungjawaban $\left(X_{3}\right)$, kemandirian $\left(X_{4}\right)$, dan kewajaran/kesetaraan $\left(X_{5}\right)$. Variabel terikat, yaitu Kualitas informasi keuangan (Y).

Transparansi merupakan keterbukaan informasi dalam perusahaan yang diwujudkan dengan menyediakan informasi yang cukup, akurat, dan tepat waktu kepada pemangku kepentingan. Prinsip transparansi diukur dengan empat indikator pertanyaan yaitu kebijakan perusahaan yang dikomunikasikan kepada pemangku kepentingan, kewajiban perusahaan dalam menyajikan informasii secara jelas, tepat waktu, transparan, dapat dibandingkan dengan perusahaan yang menyusun audit serta menyajikan informasi laporan keuangan sesuai standar akuntansi dan transparansi tidak mengurangi kewajiban untuk menjaga kerahasiaan perusahaan.

Akuntabilitas adalah kejelasan fungsi, struktur system dan pertanggungjawaban organ perusahaan. Prinsip akuntabilitas diukur dengan lima indikator pertanyaan yaitu rincian tugas serta tanggung jawab perusahaan ditetapkan dengan jelas dan sejalan dengan tujuan perusahaan seluruh karyawan memiliki kemampuan yang sesuai dengan tanggung jawab, tugas dan perannya dalam melaksanakan GCG pengelolaan internal perusahaan dikendalikan secara efektif, pengukuran kinerja diterapkan secara konsisten sesuai dengan nilai-nilai perusahaan dan seluruh karyawan dalam melaksanakan tugas serta tanggung jawabnya harus berpegangan pada etika bisnis dan pedoman prilaku yang telah disepakati.

Pertanggungjawaban adalah kepatuhan perusahaan terhadap peraturan yang berlaku, perlindungan lingkungan hidup memelihara lingkungan bisnis yang kondusif bersama masyarakat, dengan menerapkan prinsip ini perusahaan diharapkan akan menyadarkan perusahaan dalam kegiatan operasionalnya. Prinsip pertanggungjawaban diukur dengan tiga indikator pertanyaan yaitu pelaksanaan tanggungjawab sosial terhadap masyarakat serta lingkungan disekitar perusahaan telah dilaksanakan secara memadai. Perusahaan memastikan setiap karyawannya patuh pada peraturan perusahaan maupun peraturan perundangan dan perusahaan dalam melaksanakan aktivitasnya sesuai dengan prinsip ekonomi yang sehat.

Kemandirian adalah pengelolaan perusahaan yang dilakukan secara professional tanpa ada benturan kepentingan dan tanpa tekanan atau intervensi dari pihak manapun yang tidak sesuai dengan peraturan yang berlaku. Prinsip kemandirian diukur dengan empat indikator pertanyaan yaitu masing-masing organ perusahaan menghindari terjadinya dominasi oleh pihak manapun, tidak terpengaruh oleh kepentingan tertentu bebas dari benturan kepentingan dan dari segala pengaruh dan tekanan perusahaan dalam menetapkan jabatan penting dilakukan secara independen dalam aktivitasnya perusahaan tidak saling 
melempar tanggung jawab antara satu pihak dengan pihak lainnya sehingga dapat mewujudkan system pengendalian internal yang efektif dan perusahaan dalam pengambilan keputusan dilakukan dengan objektif yaitu tidak adanya tekanan dari pihak manapun.

Kewajaran dan kesetaraan merupakan prinsip yang menuntut adanya perlakuan yang adil dalam memenuhi hak stakeholder sesuai dengan peraturan perundangan yang berlaku. Prinsip kesetaraan dan kewajaran diukur dengan tiga indikator pertanyaan yaitu seluruh pemangku kepentingan maupun karyawan diberikan kesempatan yang sama dalam menyampaikan pendapat untuk kepentingan perusahaan, kesetaraan dan kewajaran yang diberikan kepada pemangku kepentingan maupun karyawan telah disesuaikan dengan kontribusi yang diberikan kepada perusahaan, dan perusahaan memberikan kesempatan yang sama baik dalam hal penerimaan karyawan, berkarir serta pelaksanaan tugas secara adil tanpa memperhatikan agama, suku, ras mapupun gender.

Kualitas informasi keuangan yang dimaksud dalam penelitian ini merupakan persepsi responden atas kualitas informasi keuangan yang telah disajikan atau dihasilkan oleh perusahaan, berguna dalam pengambilan keputusan di masa kini maupun masa depan. Kualitas informasi keuangan terdiri dari empat karakteristik yaitu relavan, andal, dapat dibandingkan dan dapat dipahami.

Populasi pada penelitian ini adalah seluruh karyawan pada kantor PERUMDA Air Minum Tirta Sewaka Darma. Berdasarkan data yang ada jumlah karyawan 340 orang. Teknik purposive sampling digunakan agar menghasilkan sampel yang representatif. Adapun kriteria sampel yang digunakan dalam penelitian ini berjumlah 56 orang. Sampel yang digunakan dalam penelitian ini adalah direktur Administrasi dan Keuangan, karyawan bagian keuangan, dan karyawan bagian umum di PERUMDA Air Minum Tirta Sewaka Darma.

Tabel 2. Data Sampel Karyawan PERUMDA Air Minum Tirta Sewaka Darma

\begin{tabular}{ll}
\hline Keterangan & Jumlah \\
\hline Direksi Adiministrasi Dan Keuangan & 1 \\
Bagian Keuangan & 17 \\
Bagian Umum & 38 \\
Jumlah & 56 \\
\hline
\end{tabular}

Sumber: Data Penelitian, 2019

Penelitian ini menggunakan metode pengumpulan data berupa kuesioner. Teknik analisis data yang digunakan, yaitu statistik deskriptif, uji asumsi klasik, analisis regresi linear berganda, dan uji hipotesis.

\section{HASIL DAN PEMBAHASAN}

Data penelitian diperoleh dari hasil kuesioner yang telah disebarkan kepada responden penelitian sejumlah 56 orang pegawai PERUMDA Air Minum Tirta Sewakadarma. Karakteristik responden meliputi usia, jenis kelamin, dan jenjang pendidikan terakhir. Hasil uji validitas menunjukkan bahwa seluruh instrumen penelitian yang digunakan untuk mengukur variabel Transparansi, Akuntabilitas, Pertanggungjawaban, Kemandirian, Kesetaraan dan Kewajaran, dan Kualitas Informasi Keuangan memiliki Inilai koefisien korelasi dengan skor 
total seluruh item pernyataan lebih besar dari 0,30 dengan signifikansi kurang dari 0,05 .

Hal ini menunjukkan bahwa butir-butir pernyataan dalam instrument penelitian tersebut valid dan layak digunakan sebagai instrument penelitian. Hasil uji reliabilitas menunjukkan bahwa seluruh instrumen penelitian memiliki koefisien Cronbach's Alpha lebih dari 0,60. Jadi dapat dinyatakan bahwa seluruh variabel telah memenuhi syarat reliabilitas atau kehandalan sehingga dapat digunakan untuk melakukan penelitian.

Tabel 3. Hasil Statistik Deskriptif Variabel Penelitian

\begin{tabular}{|c|c|c|c|c|c|}
\hline & $\mathrm{N}$ & Minimum & Maximum & Mean & Std. Deviation \\
\hline Transparansi & 56 & 12.00 & 20.00 & 16.7857 & 2.36424 \\
\hline Akuntabilitas & 56 & 12.00 & 20.00 & 16.5536 & 1.55995 \\
\hline Pertanggungjawaban & 56 & 9.00 & 15.00 & 12.4464 & 1.63951 \\
\hline Kemandirian & 56 & 9.00 & 20.00 & 16.8571 & 2.56145 \\
\hline Kewajaran dan Kesetaraan & 56 & 9.00 & 15.00 & 12.7857 & 1.42337 \\
\hline Kualitas Informasi Keuangan & 56 & 49.00 & 69.00 & 60.3036 & 4.92090 \\
\hline Valid N (listwise) & 56 & & & & \\
\hline
\end{tabular}

Sumber: Data Penelitian, 2019

Variabe transparans memiliki nilai minimum sebesar 12 dan nilai maksimum sebesar 20. Variabel transparansi yang diukur dengan 4 item pernyataan dengan bantuan skala likert 5 poin memiliki nilai rata-rata sebesar 16,78. Nilai standar deviasi variabel transparansi sebesar 2,36. Hal ini berarti nilai ini lebih rendah dibandingkan dengan nilai rata-rata, yang artinya sebaran data terkait dengan transparansi sudah merata.

Variabel akuntabilitas memiliki nilai minimum sebesar 12 dan nilai maksimum sebesar 20. Variabel akuntabilitas yang diukur dengan 5 item pernyataan dengan bantuan skala likert 5 poin memiliki nilai rata-rata sebesar 16,553. Nilai standar deviasi variabel akuntabilitas sebesar 1.55. Hal ini berarti nilai ini lebih rendah dibandingkan dengan nilai rata-rata yang artinya sebaran data terkait dengan akuntabilitas sudah merata.

Variabel pertanggungjawaban memiliki nilai minimum, sebesar 9 dan nilai maksimum sebesar 15. Variabel pertanggungjawaban yang diukur dengan 3 item pernyataan dengan bantuan skala likert 5 poin memiliki nilai rata-rata sebesar 12,446. Nilai standar deviasi variabel pertanggungjawaban sebesar 1,639. Hal ini berarti nilai ini lebih rendah dibandingkan dengan nilai rata-rata yang artinya sebaran data terkait dengan pertanggungjawaban sudah merata.

Variabel kemandirian memiliki nilai minimum sebesar 9 dan nilai maksimum sebesar 20. Variabel kemandirian yang diukur dengan 4 item pernyataan dengan bantuan skala likert 5 poin memiliki nilai rata-rata sebesar 16,857. Nilai standar deviasi variabel kemandirian sebesar 2,561. Hal ini berarti nilai ini lebih rendah dibandingkan dengan nilai rata-rata, yang artinya sebaran data terkait dengan kemandirian sudah merata.

Variabel kewajaran dan kesetaraan memiliki nilai minimum sebesar 9 dan nilai maksimum sebesar 15. Variabel kewajaran dan kesetaraan yang diukur dengan 3 item pernyataan dengan bantuan skala likert 5 poin memiliki nilai ratarata sebesar 12,785. Hal ini berarti nilai ini lebih rendah dibandingkan dengan 
nilai rata-rata, yang artinya sebaran data terkait dengan kewajaran dan kesetaraan sudah merata.

Variabel persepsi Kualitas Informasi Keuangan memilikii nilai minimum sebesar 49 dan nilai maksimum sebesar 69. Variabel Kualitas Informasi Keuangan yang diukur dengani 14 item pernyataan dengan bantuan skala likert 5 poin. memilikil nilai rata-rata sebesar 60,30. Nilai standar deviasi variabel Kualitas Informasi Keuangan sebesar 4,92. Hall ini berarti nilai ini lebih rendah dibandingkan dengani nilail rata-rata yang artinya sebaran data terkait dengan Kualitas Informasi Keuangan sudah merata.

Hasil uji normalitas diperoleh nilai signifikansi sebesar 0,963 dan nilai Kolmogrov sebesar 0,502. Oleh karena nilai signifikansi uji Kolmogorov-Smirnov lebih dari 0,05 maka dapat disimpulkan bahwa model persamaan regresi tersebut berdistribusil normal. Nilai tolerance dan, VIF, dari seluruh variabel tersebut menunjukkan bahwa nilai tolerance untuk setiap variabel lebihi besar dari 10 persen dan nilai VIF, lebih kecil daril 10 yang berarti model persamaan regresi bebas dari multikolinearitas. Nilai Signifikansi dari variabel Transparansi, Akuntabilitas, Pertanggungjawaban, Kemandirian, Kewajaran dan Kesetaraan masing-memiliki nilai yang lebihi besar dari 0,05 yang berarti tidak terdapat pengaruh antara variabel bebas terhadap absolute residual. Dengan demikian, model yang dibuat tidak mengandung gejala heteroskedastisitas.

\section{Tabel 4. Hasil. Analisis. Regresi. Linier Berganda}

\begin{tabular}{llllll}
\hline Model & \multicolumn{2}{l}{$\begin{array}{l}\text { Unstandardized } \\
\text { Coefficients }\end{array}$} & \multicolumn{2}{l}{$\begin{array}{l}\text { Standardized } \\
\text { Coefficientsi }\end{array}$} & \\
\cline { 2 - 5 } & $\mathrm{B}$ & Std. Error & Beta & Tt & Sig. \\
\hline 1 (Constant) & 13.110 & 4.117 & & 3.185 & .002 \\
Transparansi & .678 & .211 & .326 & 3.218 & .002 \\
Akuntabilitas & .738 & .330 & .234 & 2.237 & .030 \\
Pertanggungjawab-an & .665 & .316 & .221 & 2.106 & .040 \\
Kemandirian & .399 & .159 & .208 & 2.507 & .015 \\
Kewajaran & dan.673 & .295 & .195 & 2.284 & .027 \\
kesetaraan & & & & &
\end{tabular}

Sumber:, Data Penelitian, 20199

Berdasarkan hasil analisis regresi linier berganda seperti yang disajikan pada Tabel, 4. maka dapat dibuat persamaan regresi sebagai berikut.

$$
Y=13,110+0,678 X_{1}+0,738 X_{2}+0,665 X_{3}+0,399 X_{4}+0,673 X_{5}
$$

Nilai koefisien regresi masing-masing variabel bebas bernilai positif dengan nilai signifikansi uji t kurang dari 0,05. Hal ini menunjukkan bahwa semua variabel bebas memiliki pengaruh positif yang signifikan terhadap variabel terikat. Berikut penjelasan mengenai hasil analisis regresi berganda, terdiri atas koefisien determinasi $\left(\mathrm{R}^{2}\right)$, uji kelayakan model (uji $\mathrm{F}$ ), dan uji hipotesis (uji t).

Nilai Adjusted $R$ Square sebesar 0,735 mempunyai arti bahwa sebesar 73,5 persen variasi kualitas informasi keuangan pada PERUMDA Air Minum Tirta Sewakadarma dipengaruhi oleh variasi transparansi, akuntabilitas, pertanggungjawaban, kemandirian, kewajaran dan kesetaraan, sedangkan sisanya sebesar 26,5 persen djelaskan oleh faktor lain yang tidak dimasukkan ke

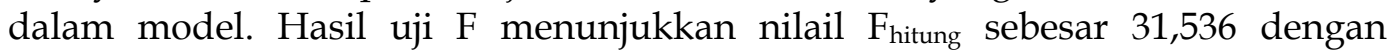


signifkansi sebesar 0,000 $<0,05$, maka dapat disimpulkan bahwa pada kelompok yang diuji memiliki perbedaan yang nyata (signifikan). Hasil ini mempunyai arti bahwa secara simultan Transparansi, Akuntabilitas, Pertanggungjawaban, Kemandirian, Kewajaran dan Kesetaraan berpengaruh signifikan terhadap kualitas informasi keuangan pada PERUMDA Air Minum Tirta Sewakadarma. Hasil uji hipotesis menunjukkan nilai signifikan $X_{1}=002, X_{2}=0,030, X_{3}=0,040$, $X_{4}=0,015$, dan $X_{5}=0,027$, yang berarti bahwa variabel independen berpengaruh signifikan secara bersama-sama pada variabel dependen.

Transparansi berpengaruh positif dan signifikan pada Kualitas Informasi Keuangan. Semakin tinggi tingkat transparansi laporan keuangan pada PERUMDA Air Minum Tirta Sewakadarma maka kualitas informasi keuangan yang dihasilkan akan semakin meningkat. Temuan penelitian ini sesuai dengan teori keagenan, yang menyatakan bahwai agen lebih banyak tahu tentang informasi perusahaan, sehingga untuk menghindari terjadinya asimetri informasi diperlukan keterbukaan informasi atau transparansi. Transparansi memberikan informasi keuangan yang terbuka dan jujur kepada principal berdasarkan pertimbangan bahwa principal memiliki hak untuk mengetahui secara terbuka dan menyeluruh atas pertanggungjawaban agen dalam pengelolaan sumber daya yang dipercayakan kepadanya (Mursyidi, 2009). Hasil penelitian ini mendukung penelitian Taufan (2016) yang menyatakan bahwa variabel transparansi berpengaruh signifikan terhadap kualitas laporan keuangan.

Akuntabilitas berpengaruh positif dan signifikan pada Kualitas Informasi Keuangan. Semakin tinggi tingkat akuntabilitas laporan keuangan pada PERUMDA Air Minum Tirta Sewakadarma maka kualitas informasi keuangan yang dihasilkan akan semakin meningkat. Temuan penelitian ini sesuaii dengan teori keagenan yang menyatakan bahwa Akuntabilitas merupakan kewajiban bagi agen untuk memperhatikan stakeholder atas kegiatan dan pencapaian dalam suatu Organisasi Lembaga maupun Perusahaan. Prinsip akuntabilitas sejalan dengan teori agen dimana dua pihak yang ada dalam konsep akuntabilitas dideskripsikan sebagai principal dan agent. Hasil penelitiani ini mendukung penelitian Devi (2018) yang menyatakan bahwa prinsipi akuntabilitas berpengaruh positif pada kualitas informasi keuangan.

Pertanggungjawaban berpengaruh positif dan signifikan pada Kualitas Informasi Keuangan. Semakin tinggi penerapan prinsip pertanggungjawaban laporan keuangan pada PERUMDA Air Minum Tirta Sewakadarma maka kualitas informasi keuangan yang dihasilkan akan semakin meningkat. Temuan penelitian ini sesuai dengan teori stewardship, yang menyatakan bahwa Pertanggungjawaban perusahaan merupakan kesesuaian tata kelola perusahaan pada peraturan perundangan serta prinsip-prinsip perusahaan yang sehat. Aktivitas perusahaan harus mampu memastikan bahwa seluruh organ perusahaan patuh pada peraturan perusahaan maupun peraturan perundangan, sehingga perusahaan akan bertanggung jawab atas informasi keuangan perusahaan. Berdasarkan teori stewardship yang menggambarkan para manajer tidak termotivasi oleh tujuan-tujuan individu tetapi lebih merujuk kepada sasaran hasil utama demi kepentingan organisasi (Riyadi dan Yulianto, 2014). Hasil penelitian ini mendukung penelitian Devi (2018) yang menemukan hasil 
bahwa prinsip pertanggungjawaban berpengaruh positif pada kualitas informasi keuangan.

Kemandirian berpengaruh positif dan signifikan pada Kualitas Informasi Keuangan. Semakin tinggi penerapan prinsip kemandirian laporan keuangan pada PERUMDA Air Minum Tirta Sewakadarma, maka kualitas informasi keuangan yang dihasilkan akan semakin meningkat. Temuan penelitian ini sesuai dengan teori stewardship, yang menyatakan bahwa Independensi merupakan bentuk pengambilan keputusan dengan objektif, sehingga pengelolaan perusaahaan harus dilakukan secara independen yaitu tidak saling mempengaruhi maupun saling mendominasi. Sesuai dengan teori stewardship dimana kepentingan bersama dijadikan dasar dari tindakan manajer. Sehingga manajer tidak mudah terpengaruh dengan kepentingan-kepentingan lainnya karena manajer berusaha sebaik mungkin dalam menyampaikan informasi keuangan demi sasaran atau tujuan perusahaannya. Hasil penelitian ini mendukung penelitian Devi (2018) yang menyatakan bahwa prinsip kemandirian berpengaruh positif pada kualitas informasi keuangan.

Kewajaran dan Kesetaraan berpengaruh positif dan signifikan pada Kualitas Informasi Keuangan. Semakin tinggi penerapan prinsip kewajaran dan kesetaraan laporan keuangan pada PERUMDA Air Minum Tirta Sewakadarma, maka kualitas informasi keuangan yang dihasilkan akan semakin meningkat. Temuan penelitian ini sesuai dengan teori keagenan, yang menyatakan bahwa perusahaanl dalam melakukan aktivitas operasional harus memberikan perhatian yang berhubungan mengenai kepentingan para stakeholder berdasarkan pada prinsip kesetaraan dan kewajaran. Hubungan antara agen dan principal harus saling memberi umpan balik, sehingga agen akan memberikan informasi keuangan sesuai dengan apa yang diharapkan principal untuk itu kesetaraan dalam perusahaan penting. Sehingga dapat dikatakan kewajaran dan kesetaraan berpengaruh dalam pencapaian kualitas informasi keuangan. Hasil penelitian ini mendukung penelitiani (Devi, 2018) yang menyatakan bahwa prinsip kewajaran dan kesetaraan berpengaruh positif pada kualitas informasi keuangan.

\section{SIMPULAN}

Berdasarkan hasil penelitian yang telah diuji melalui pengujian statistik menunjukkan bahwa transparansi, akuntabilitas, pertanggungjawaban, kemandirian, dan kewajaran/kesetaraan berpengaruh positif signifikan pada persepsi kualitas informasi keuangan PERUMDA Air Minum Sewaka Darma. Hal ini berarti semakin tinggi tingkat transparansi laporan keuangan, maka kualitas informasi keuangan yang dihasilkan akan semakin meningkat. Semakin tinggi tingkat akuntabilitas laporanl keuangan, maka kualitas informasi keuangan yang dihasilkan akan semakin meningkat. Semakin tinggi penerapan prinsip pertanggungjawaban laporanl keuangan maka kualitasinformasi keuangan yang dihasilkan akan semakin meningkat. Semakin tinggi penerapan prinsip kemandirian laporan keuangan, maka kualitas informasi keuangan yang dihasilkan akan semakin meningkat. Semakin tinggi penerapan prinsip kewajaran dan kesetaraan laporan keuangan. Hasil penelitian ini diharapkan dapat menjadi pertimbangan baik bagi perusahaan maupun peneliti selanjutnya. 


\section{REFERENSI}

Arifin. (2018). Pengaruh Audit Kinerja dan Pengendalian Intern Terhadap Kinerja Perusahaan Daerah Air Minum (PDAM) Kota Gorontalo Dengan Good Corporate Governance Sebagai Variabel Intervening. Bongaya Journal for Research in Accounting, 1(1), 48-57.

Barrett, P. (1997). A Joint Seminar by IPAA and ASCPAs as part of a Panel Discussion on "Governance and the Role of the Senior Public Executive ", Canberra Corporate Governance and Accountability for Performance. (August).

Chaarani. (2014). The impact of corporate governance on the performance of Jordanian banks. European Journal of Scientific Research, 67(3), 349-359.

Devi, K. T. W. (2018). Pengaruh Prinsip-Prinsip Good Corporate Governance Pada Kualitas Informasi Keuangan Pdam Kabupaten Buleleng. 23, 2311-2334.

Dewi, N. F., Ferdous Azam, S. M., \& Yusoff, S. K. M. (2019). Factors influencing the information quality of local government financial statement and financial accountability. Management Science Letters, 9(9), 1373-1384. https://doi.org/10.5267/j.msl.2019.5.013

Donaldson, L., \& Davis, J. H. (1991). Stewardship Theory or Agency Theory: CEO Governance and Shareholder Returns. Australian Journal of Management, (June 1991), 49-66.

Eisenhardt, K. M. (1989). Linked references are available on JSTOR for this article: Agency Theory: An Assessment and Review. 14(1), 57-74.

Emilia Peni, Stanley D. Smith, A., \& Va“ha"maa, S. (2002). Bank Corporate Governance and Real Estate Lending During the Financial Crisis.

Fathi, J. (2013). Corporate governance system and quality of financial information. Mediterranean Journal of Social Sciences, 4(2), 129-142. https://doi.org/10.5901/mjss.2013.v4n2p129

Gapsalamov, A. R., Vasilev, V. L., \& Ilyin, A. G. (2017). State planning of the Russian economy: Past and present. International Journal of Economic Perspectives, 11(1), 474-480.

Gordon, B. D. (2002). Sistem Informasi Manajemen. Jakarta: PTM.

Haque, F., Arun, T., \& Kirkpatrick, C. (2008). Corporate governance and capital markets: A conceptual framework. Corporate Ownership and Control, 5(2 C CONT. 2), 264-276.

Hart, O. (1995). Corporate Governance : Some Theory and Implications Author ( s ): Oliver Hart Published by: Wiley on behalf of the Royal Economic Society Stable URL: https://www.jstor.org/stable/2235027. The Economic Journal, 105(430), 678-689.

Hindistari, R., \& Asri Dwija Putri, I. (2016). Pengaruh Penerapan Prinsip-Prinsip Good Corporate Governance Pada Kinerja Bank Perkreditan Rakyat Kabupaten Gianyar. E-Jurnal Akuntansi, 16(1), 101-128.

Ikatan Akuntan Indonesia. (2007). Standar Akuntansi Keuangan. Jakarta: Salemba Empat.

Jensen, M. C., \& Meckling, W. H. (1976). Theory of the Firm: Managerial. Journal of Financial Economics, 3, 305-360. https://doi.org/http://dx.doi.org/10.1016/0304-405X(76)90026-X

Kamazima, B. K., Mathenge, P., \& Ngui, T. (2017). Performance: A Case of Listed Commercial Banks in Kenya. 4, 60-82. 
KNKG. (2006). Pedoman Umum Good Corporate Governance Indonesia.

M'Ithiria, E. N., \& Musyoki, D. (2014). Corporate Governance , Ownership Structure Perspective and Firm Value: Theory, and Survey of Evidence. International Journal of Research in Management $\mathcal{E}$ Business Studies IIRMBS, 1(3), 57-61.

Mahaendrayasa dan Putri. (2017). Pengaruh Prinsip-Prinsip Good Corporate Governance Terhadap Kinerja Keuangan Lembaga Perkreditan Desa (Lpd) Di Kota Denpasar. E-Jurnal Akuntansi Universitas Udayana, 21(2), 970-995.

Mursyidi. (2009). Mursyidi.pdf. Bandung: PT. Refika Aditama.

Noviolanita, C. (2015). Pengaruh Penerapan Good Corporate Governance Terhadap Kualitas Laporan Keuangan. Star-Studi and Accounting Research, XI(3). Retrieved from https://repository.widyatama.ac.id/xmlui/handle/123456789/4674

Osadchy, E. A., Akhmetshin, E. M., Amirova, E. F., Bochkareva, T. N., Gazizyanova, Y. Y., \& Yumashev, A. V. (2018). Financial statements of a company as an information base for decision-making in a transforming economy. European Research Studies Journal, 21(2), 339-350.

Pradnyaswari, L., \& Putri, I. (2016). Pengaruh Prinsip-Prinsip Good Corporate Governance Pada Kinerja Keuangan Koperasi Di Kabupaten Klungkung. E-Jurnal Akuntansi, 14(2), 1064-1091.

Putra Sejati, E. (2018). Pengaruh Good corporate Governance terhadap Kinerja Keuangan pada Perusahaan Manufaktur Industri Real Estate dan Property di BEI. Seminar Nasional Dan Call for Paper, 794-807.

Putri, K. I. H., \& Wirajaya, I. G. A. (2017). Pengaruh Kinerja Keuangan Pada Nilai Perusahaan Dengan Good Corporate Governance Sebagai Variabel Pemoderasi. E-Jurnal Akuntansi Universitas Udayana, 21(1), 1-28.

Rahmatika, N., \& Agusti, R. (2015). Pengaruh Penerapan Prinsip-Prinsip Good Corporate Governance Terhadap Kinerja Keuangan Perusahaan (Studi pada PT Angkasa Pura II). Jurnal Akuntansi, 3(2), 148-159.

Riyadi, S., \& Yulianto, A. (2014). Pengaruh Pembiayaan Bagi Hasil, Pembiayaan Jual Beli, Financing To Deposit Ratio (Fdr) Dan Non Performing Financing (Npf) Terhadap Profitabilitas Bank Umum Syariah Di Indonesia. Accounting Analysis Journal, 3(4), 473.

Sari, Y. A. (2015). Pengaruh Penerapan Good Corporate Governance terhadap Informasi Kinerja Keuangan (Vol. 2). https://doi.org/10.24815/jdab.v2i1.3613

Taufan, M. I. (2016). Pengaruh Transparansi dan Kauntabilitas Terhadap Kualitas Laporan Keuangan Pemerintah Daerah Kota Bandung. (Vol. 53). https:/ / doi.org/10.1017/CBO9781107415324.004

Vintila, G., \& Gherghina, S. C. (2012). An Empirical Examination of the Relationship between Corporate Governance Ratings and Listed Companies' Performance. International Journal of Business and Management, 7(22). https:// doi.org/10.5539/ijbm.v7n22p46

YPPMI, I. (2002). Good Corporate Governance dalam Konsep dan Implementasi Perusahaan Publik dan Korporasi Indoonesia. YPPMI Sinergy Comunication. 